\title{
ЦИТОПРОТЕКТОРНЫЕ СВОЙСТВА ПИРИМИДИНОВЫХ ПРОИЗВОДНЫХ ГУАНИДИНА
}

\author{
Н.А. Гурова', А.А. Озеров ${ }^{1,2}$, В.В. Вишневская ${ }^{1}$, В.Н. Перфилова ${ }^{1,2}$, \\ В.С. Сиротенко', Н.В. Овсянкина', М.В. Кустова', Д.В. Мережкина, ${ }^{1,2}$
}

${ }^{1}$ Волгоградский Государственный Медицинский Университет Минздрава РФ, 400131, Россия, г. Волгоград, пл. Павших Борцов, 1.

2ГБУ Волгоградский медицинский научный центр, 400131, Россия, г. Волгоград, пл. Павших Борцов, 1.

DOI: 10.19163/MedChemRussia2021-2021-89

E-mail: gurova.vlgmed@mail.ru

В исследованиях in vitro изучена NHE-1-ингибирующая активность 13 соединений - пиримидиновых производных гуанидина с лабораторными шифрами «VMA», из которых 9 относится к производным хиназолина (бензопиримидина), содержащим незамещенную гуанидиновую группу; 4 соединения - к производным урацила (пиримидин-2,4(1Н,3Н)-диона), имеющим незамещенную гуанидиновую группу. Все соединения превосходили препарат сравнения зонипорид как по NHE-1-ингибирующей активности в концентрации $1 \times 10-8$ М, так и по величине $\mathrm{EC}_{50}$. При изучении зависимости фармакологической активности от химической структуры наиболее активными оказались соединения производных хиназолина, содержащие в положении С6 бром.<smiles>CC(C(=O)OCc1ccccc1)N(C)C(=O)C=Nc1ccc(Br)cc1C(=O)N(C)C(C)C(=O)NC(=N)N</smiles>

VMA-13-21

У соединения-лидера VMA-1321 были выявлены противоишемические, антифибрилляторные и кардиопротекторные свойства. Вещество VMA-13-21 ограничивает повреждающее действие изопротеренола на миокард (по показателям функционального состояния митохондрий клеток сердца: уровню МДА, активности СОД, сопряжению процессов окисления субстратов и синтеза АТФ; гипертрофии миокарда; количеству конечных метаболитов NO), улучшает сократительную активность миокарда и функциональные резервы, ограничивает вероятность возникновения тромбогенных осложнений при экспериментальной хронической сердечной недостаточности, оказывает эндотелиопротекторное действие. 